\title{
Роль сербской церкви в сохранении национального самочувствия сербского народа во время турецкого владычества
}

\begin{abstract}
Subotin-Golubović Tatjana, Rol' serbskoj cerkvi v sohranenii nacional'nogo samočuvstvija serbskogo naroda vo vremja tureckogo vladyčestva (The Role of the Serbian Church in Maintaining National Identity of the Serbian Nation under Turkish Rule). „Poznańskie Studia Slawistyczne” 5. Poznań 2013. Adam Mickiewicz University Press, pp. 281-293. ISBN 978-83-232-2636-9. ISSN 2084-3011.

The re-establishment of the autocephality of the Serbian Church in 1557 instigated a considerable degree of activity in the field of cultural restoration. The see of the Patriarchate was revived in its former location - in the monastery Peć. Restoration of the structures of the church organization was accompanied by reparation of the old (abandoned or neglected) churches and monasteries, as well as by building of new objects. A number of new churches and monasteries arouse in the regions of the Balkans which were colonized by Serbs intensively and systematically. The new churches required liturgical books necessary for non-hindered performance of the rite. The result was that old scriptoria were restoring and intensifing their activity, but at the same time new scriptoria started to fill the libraries of numerous churches and monasteries. The short supply of liturgical books towards the end of the $15^{\text {th }}$ century motivated Djurdje Crnoevic to establish the first printing shop in the South Slavonic lands at Cetinje. During the first half of the $16^{\text {th }}$ century there were several printing shops at Goražde, in the monastery of Rujan and in the monasteries Gračanica and Mileševa. An analysis of the production of all those printing shops show that exclusively books necessary for normal performance of the rite were printed.
\end{abstract}

Keywords: Serbian Church; clergy; monastery; scriptorium; print shop; Turkish rule

Битва на Косовом поле (в 1389 г.) сыграла решающую роль в дальнейшей судьбе сербского народа. К этому времени не было больше династии Неманичей, чьей последний отпрыск, царь Стефан Урош V (сын царя Душана) умер бездетным в 1371 году. Хотя разложение некогда единого и могущественного государства началось еще 
при его жизни, после 1371 г. (когда произошло и первое большое сражение с турками) оно окончательно распалось на целый ряд самостоятельных областей, которыми правили бывшие царские вельможы. Особое место между ними занимал князь Лазарь, который предъявил свои права на правление сербскими землями опираясь на родственые связи с Неманичами (его жена Милица была прямым потомком основателя династии - Немани, от его самого старшего сына Вукана). После трагической гибели Лазаря в 1389 году, за малолетством детей, териториями унаследоваными от мужа правила княгиня Милица. Ей пришлось вступить в дипломатические сношения с турками, и даже послать в султанский гарем одну из дочерей (Оливеру). В 1402 г. Стефан, будучи самым старшим сыном и официальным наследником князя Лазаря, получил в Цариграде титул деспота, от чего и земли которыми он правил стали называтся Деспотовина (Српска Деспотовина). Столицей Деспотовины временно стал город Белград который Стефан, став и вассалом венгерской короны, получил от венгров, но после его смерти в 1427 г. город снова отошел венграм. Стефан умер бездетным, выбрав предварительно себе в наследники своего племяника Ђурђа (Георгия) Бранковича (1427-1456). Георгий построил новую столицу - город Смедерево на Дунае. Преемником деспота Георгия стал его самый младший сын Лазарь ${ }^{1}$, который умер два года спустя. Так как у Лазаря были только дочери, страной правили наместники: его вдова Елена Палеолог и ее деверь слепой деспот Стефан, которые искали союзников на Западе считая, что туркам необходимо дать отпор, и воевода Михаил (,Аранђеловић”) который надеялся, что сохраняя вассальное положение по отношению к туркам, ему удастся обеспечить хотя бы видимость определенной государственой самостоятельности. Последним правителем Деспотовины стал, женившись на Елене (дочери деспота Лазаря), Стефан Томашевич, сын боснийского короля Стефана Томаша. Смедерево мирно сдалось туркам 20. июня 1459 года, чем и закончилось существование самостоятельного сербского государства (Калић 1994: 127-146; Спремић 1994).

\footnotetext{
1 Два старших сына были ослеплены по приказанию султана Мурата II еще в 1441 году и по этому не могли стать полноценными правителями страны. В 1446 г. наследником стал младший сын Лазарь, который еще в 1444 году женился на Елене Палеолог, племянице царя Иоанна VIII Палеолога, и в том же году получил титул деспота.
} 
Сербская церковь стала самостоятельной (автокефальной) в 1219 г. благодаря труду и стараниям святого Саввы Сербского (в миру Растка, самого младшего сына Немани, в монашестве Симеона). До этого, сербские земли находились в подчинении у Охридской архиепископии. Савва стал первым сербским архиепископом. На протяжении всего существования независимого сербского государства можно проследить удачно сложившиеся отношения (полную симфонию) между светскими и церковными властями. При каждом владетеле находился архиепископ (после 1347 г. - патриарх) который полностью поддерживал государственную политику владетеля. Среди этих священослужителей немалое число были люди выдающиихся качеств (видные политики, дипломаты, писатели).

Но и после больших потрясений которые сербская церковь пережила на протяжении почти ста лет (до 1459), ей после потери государственной самостоятельности удалось в основном сохранить свою структуру и организацию и, что важнее всего, свой авторитет в народе.

Турки проникли в Европу уже став мусульманами; за собой они повлекли странную смесь дервишей и их последователей, мистиков, всевозможных восточных авантюристов которые выдавали себя за пророков (Самарџић 1993а: 7-9). Честно надо сказать, что на Балканах в это время все еще существовали захолустья чье населние, хотя давно приняло христианство, в значительной степени было неразвито и отстало. В такой среде, в особености из-за недостаточного присутствия, или даже - отсутствия крепкой руки християнской церкви, легко снова возрождались старые языческие обычаи и прививались разные ереси. Турки, естественно, старались увеличить число „правоверных" то есть мусульман, и их первой добычей становились именно люди колеблющиеся в своей вере. Определеное число знатных сербов приняло новое вероисповедание, надеясь благодаря этому сохранить свое имущество и социальное положение и таким образом снова попасть в властвующее сословие. Но сербы не сдавались легко, отпор протянулся почти на сто лет. Сербский народ показал способность выжить и в очень тяжелых условиях, и то в первую очередь благодаря степени развития сербского средневекового общества. В средневековой Сербии была учреждена такая сословная система, благодаря 
которой все были в материяльном смысле, обеспечены основными средствами для жизни, но зато каждое сословие должно было точьно выполнять свои объязаности в отношении к государству и церкви, установленные законами и грамотами которые выдавались служилым людям и монастырям (Самарџић 1993а: 15). Самым большим феодалом в средневековой Сербии является именно церковь, что видно по сохранившимся грамотам (Ивић, Грковић 1976; Мишић, Суботин-Голубовић 2003; Трифуновић 2011) ${ }^{2}$, и даже во время турецкого владычества ей удалось сохранить значительные земельные уделы, которыми она была щедро одарена в предыдущие века. Нелегкая судьба выпала на долю сербской церкви. Паралельно с турецким продвиганием на север к Дунаю, церковь теряла свои эпархии. Последний сербский патриарх Арсений II жил в Смедерево так как оба старых патриарших стола (Жича и Печ) находились в то время уже в турецких руках. О судьбе сербской церкви во второй половине XV века мало что известно. К сожалению, турецкие источники которые могли бы нам помоч, не исследованы в достаточной степени. Встречаются имена отдельных епископов и митрополитов, но эти скудные данные не позволяют нам восстановить полную картину того, что происходило (Ћирковић 1964: 108; Нилевић 1990: 71-72; Стојановић 1902: 353; Драговић 1887: 254) ${ }^{3}$. Не мало интересны факты с которыми нас, однако, знакомят турецкие дефтеры (налоговые книги) области Браничево за 1467 и 1476 годы. В них поминаются только те церкви и монастыри, которые имели доходы и платили налоги. Благодаря этим источникам мы знаем, что в каждом селении которое имело свыше 30 домов был и священик, а в деревнях побольше - даже и по два (Миљковић, Крстић 2007: 201-205). По мнению некоторых наших историков церкви, непосредственно после взятия турками Смедерева, сербская церковь подчинилась Охридской архиепископии (Грујић

${ }^{2}$ Сохранились грамоты выданые большим монастырям - Дечаны, Архангельскому монастырю, Баньской.

3 Так, на пример, нам известны некоторые имена митрополитов Герцеговины: Давид (1466-1471), кир Иоанн (1508-1513), Висарион (1524), Максим (1532) и Никанор (1547). В источниках того времени зафиксированы и имена епископов и митрополитов Зеты: Иосиф (1453), митрополит Висарион (1484-1485), Вавила (1493-1495), митрополит Ромил (1530). 
1920: 72; Новаковић 1923). Никакой документ который бы это подтвердил до сих пор не обнаружен. Повидимому, всего лиш в начале XVI века была предпринята серьезная попытка подчинить сербскую церковь Охриду, что и вызвало бунт сербского клира, во главе которого стал митрополит смедеревский Павел. В Охриде сохранились акты суда над Павлом, но он постановлений суда не признал (Костић 1922: 32-39). Ученными высказано и мнение о том, что документы эти подложные. Судя по обвинениям, Павел стремился полностью восстановить сербскую церковь такой, какой она была раньше, а себя поставить патриархом. Но, у него не было турецкой поддержки, без которой ничего такого нельзя было сделать. На протяжении почти всего XVI века турки всерьез занались внутренней организацией огромной територии своего государства. В то же время они обратили внимание и на состояние христианских церквей в землях приобретенных на Балканах. В первой половине XVI века целый ряд выходцев из сербской среды занимал высокие места в государственой администрации и имел большое влияние на внутреннюю и внешнюю политику Турции. В то же время когда Рустем паша Опукович (серб по происхождению) стал великим везирем, на месте третьяго везиря Порты находился его соотечественник Мехмед паша Соколович, и они оба были зятями царского дома. Судя по всему, сербская патриархия была снова восстановлена в 1557 г. именно их совместными усилиями и то, в первую очередь, по политическим причинам (Самарџић 1987: 187194). Первым патриархом стал Макарий, блиский родственник Мехмед паши, который до этого был монахом в Милешеве. По некоторым косвенным данным Макарий одно время прожыл на Афоне. Туркам необходимо было заручится преданостю и сотрудничеством сербов, так как их стали населять на пустующие територии Боснии. Учреждение новых епархий следовало за административным делением новоприобретенных земель. Сербская патриархия правила обширной територией, в которую вошли и земли над которыми она раньше не имела никакой юрисдикции (Босния, части Болгарии), а патриарх снова занял стол в старой резиденции - в комплексе церквей которые находятся недалеко от Печи (Самарџић 1993б: 7-102). Первых четыри патриарха (Макарий, Антоний, Герасим и Саватий) были Соколовичи 
и родственики Мехмед паши (Јиречек 1959: 387-392; Чубриловић 1960: 163-189; Ђурђев 1964; Самарџић 1993в: 39-53) ${ }^{4}$. Вновь восстановленная сербская церковь правила сербским народом, что в турецком теократическом государстве считалось вполне нормальным явлением. Церковь получила привилегии очень похожие на те, которые уже приобрела Цариградская патриархия. Выбор патриарха, митрополитов и епископов подтверждал своим актом (,берат”) султан, и он был действителен только при жизни того или другого. В новых обстоятельствах патриарх стал не только духовным, но и политическим вождем своего народа. Сербам была предоставлена полная свобода при выборе патриарха (после первого - Макария), митрополитов и епископов. Берат патриарха в первое время стоил 100000 акчей. Никто из архиереев не мог занять свою кафедру до того как уплатить сумму требуемую за берат. Сумма которая выплачивалась туркам зависила от величины територии, числа монастырей которые там находились, от числа белого и черного духовенства, а так же и от числа християнского населения. В источниках встречаются и известия о том, что отдельные эпархии иногда по долго были пустыми потому, что выбранный архиерей не мог собрать сумму нужную на получение берата. Турецкие власти не вмешивались во внутрение дела сербской церкви (Hadrovics 1947; Мирковић 1965). Первой целю церковь поставила перед собой заботу о восстановлении храмов - монастырей и приходских церквей. Хотя официально турки позволяли только восстанавливать те храмы которые существовали до их прихода, по мнению ученых которые занимались историей сербской церкви, патриарх Макарий получил негласное разрешение строить новые церкви и учреждать монастыри там, где их раньше не было. Это можно объяснить тем фактом, что на обширных териториях которые оказались под юрисдикцией Сербской церкви, сербы в большем числе на-

${ }^{4}$ Будущий видный политик Отоманской империи принял мухамеданское вероисповедание будучи семнадцтилетним юношей, после того как турецкие чиновники выбрали его и, вместе с другими юношами и девушками, увели в Стамбул. Это были подати „в крови” которые турки периодически брали со своих подданых християн. Известно, что Байо Соколович (будущий Мехмед паша) исполнял должность чтеца в монастыре Милешева, который в то время являлся одним из самых богатых и влиятельных сербских монастырей. 
селили и те края, где их раньше было очень мало, или где они раньше не жили и где не было православных храмов (Шупут 1984; Шупут 1991). Церкви стали строится не только в новых эпархиях, но и в старых. Сам Макарий построил церковь в деревне Будисавци (на Косове), восстанавливая таким образом старые сербские традиции. Как ученые уже отметили, неграмотные крестьяне, купцы, монахи и попы не смирялись с тем, что по мнению некоторых, жизнь как бы остановилась в 1459 году. Кроме зодческой деятельности ожила и работа живописцев. Украшались не только новые храмы, но и старые получили новую живопись (Петковић 1965). Но, кроме старых, в росписи появляются и новые темы - сцены из житий сербских святых - святого Саввы и его отца Стефана Немани (Суботић 1979: 343-354). Благодаря такому тонко продуманому иконографическому репертуару, прихожане постоянно были окружены образами которые напоминали о славном прошлом. Нам известны имена целого ряда художников тех времен - Радул (Ракић 1998), Андрея Раичевич (Милосављевић 2005), и самый известный среди них - иеромонах, художник, иконописец и писатель Лонгин Зограф. То, что известно о его жизни наглядно показывает, что происходило в сербской среде во второй половине XVI века. До наших дней частично сохранились фрески которые Лонгин писал в монастыре Ломница в северовосточной Боснии, а так же и те, которые он писал в монастыре Милешево и в самой Печи (Шево 1999). Сохранилось и значительное число икон его письма, из которых большинство сегодня хранится в монастыре Дечаны в котором Лонгин осел. В комплексе церквей в Великой Хоче (на Косове) тоже хранятся иконы которые писал Лонгин (Шакота 1956: 156-166; Шакота 1965: 533-540). Дечанский иеромонах Лонгин написал акафист святому королю Стефану Дечанскому, в котором сказался еще один его талант (Шакота 1963: 205-218). Среди многочисленых икон Лонгина, особое место занимает житийная икона короля Стефана Дечанского, на которой представлена битва у Велбужда (1330); это первый реальный сюжет сербской истории который появился в сербском искусстве (Ђурић 1985).

После восстановления патриархии и создания относительно благоприятных, насколько это вообще возможно в такие времена, усло- 
вий для жизни церкви, следовало так же занятся обеспечиванием нужных утварей и книг для повседневных церковных нужд (Суботин-Голубовић 1999). Писцы стали работать в многих местах, и не только в монастырских скрипториях, но и в приходских храмах и даже в частных домах (Момировић 1967: 89-109). Интересное явление этого времени представляют путешествующие дяки, которые принимают заказы на писание книг (Младеновић, Штављанин-Ђорђевић 1982: 101-146). В первое время заказчики самый большой интерес проявляли к богослужебным книгам, но постепено, с приобретением определенной уверености, в сербской среде начал проявлятся интерес и к книгам иного содержания. Особо чтились тексты полемического содержания «на латинян» или «против латинской ереси». Причину этому надо искать в том, что в 1624 году в Риме была основана Конгрегация для пропаганды веры, которая прилагала большие усилия, что-бы учредить унию в сербских землях (Радоњић 1950; Јачов 1983; Јачов 1986). Папа Урбан II даже открыто обратился патриарху Пайсию предлагая ему унию, но патриарх очень спокойно и с большим дипломатическим умением от унии отказался. Пайсий стал патриархом в трудное время, в 1614 году, после периода в течении которого сербская церковь пережыла новые потрясения. Во главе восстания которое сербы подняли в Банате в 1594 году стоял Федор (Теодор), владыка города Вршца, вместе с попами и монахами своей эпархии (Самарџић et al. 1993: 217-218, 232-247). В это время церковью правил патриарх Иоанн (Јован) II (1592-1614). Он старался восстановит отношения с европейскими государствами, а его посланец, Дамиян Любибратич, монах Печского монастыря, вел переговоры в Риме, Неаполе, Флоренции, Мадриде. Патриарх Иоанн был вызван в Стамбул, где и умер в 1614 году. Действия патриарха Иоанна вызвали большые опасения и недоверие у турецких властей. По этому, перед его приемником Пайсием встала трудная задача - заверить турецкие власти, что сербы являются верными поддаными султана.

Пайсий (1614-1647), став патриархом, старался наладить хорошие отношения с турецкими властями и обеспечить как можно боле благоприятные условия проживания для своего народа, для чего, после бурных событий предыдущих лет, требовалось большое политическое и дипломатическое умение. Пайсий был большим книголюб- 
цем; он не только читал и собирал разные книги, но был и хорошим писцом. До наших дней дошли не только рукописи написаные его рукой (Јовановић 1990: 243-248), но и много записей и помет в разных рукописях, которые свидетельствуют о его интересах и глубоких познаниях. Пайсий много путешествовал по обширной територии своего патриархата, собирая списки ретких литературных произведений. Он и сам был видным писателем. Как уже отмечено учеными, литературные произведения Пайсия являются завершающим звеном в развитии сербской средневековой литературы. Он написал службы и жития двум членам династии Неманичей, чьи культы не получили своей литературной и литургической обработки в боле ранее время: первому сербскому королю Стефану Первовенчаному и второму сербскому царю Стефану Урошу V, сыну царя Душана (Пајсије 1993; Јовановић 2001).

Содержание определенного числа рукописей этого времени приводит нас в недоумение, так как в них появляются очень реткие, к тому времени уже вышедшие из употребления тексты. Так, на пример, в рукописи конца XVI века, написаной в заброшеной боснийской деревне рукою сельского попа, появилась служба святому Иоанну Рильскому в своем древнейшем виде (Суботин-Голубовић 2004: 135-145) 5 . Аверкий, монах хиландарский, занимался собиранием и редактированием сборников с житиями святых и похвалами, в результате чего появилось девять объемистых рукописей которые и по сей день хранятся в Хиландаре (Богдановић 1978: 168-172; Синдик 1995: 377-393).

Желая обеспечить себе материяльную помощ и поддержку, сербская церковь всеми усилиями старалась восстановить отношения с Великим княжеством московским, видя в нем единственное православное государство к которому можно обратится за помощию и поддержкой. Это попыталась сделать еще Ангелина, сноха последняго сербского деспота Лазаря, которая была замужем за его слепым братом Стефаном. Ангелина Бранкович в 1508 году обратилась к великому князю московскому Василию III с просьбой о духовном покровительстве и о пожаловании милостыни на строительство церкви св.

\footnotetext{
5 Рукопись в которой сохранился древний вариант службы Иоанну Рильскому хранится в Музее Сербской православной церкви в Белграде (№ 32).
} 
Иоанна Златоуста, для захоронения там мощей своего супруга св. деспота Стефана и сына св. деспота Иоанна (Долгова et al. 2009: 205206). Полученые средства были, по видимому, использованы и на строительство монастыря Крушедол (1509-1516) в который, после взятия турками Белграда (1521), была перенесена кафедра белградско-сремской митрополии, во главе которой стоял другой сын Ангелины, владыка Максим.

За восстановлением Патриархии последовала очень живая комуникация с Москвой, о чем наглядно свидетельствуют многочисленые сохранившиеся документы Посольского приказа (Димитријевић 1900: 201-289; Димитријевић 1903: 16-42; Димитријевић 1922; Ђерић 1909: $2-11)^{6}$. Некоторые сербские монастыри восстановили и живо поддержывали отношения с Москвой. Среди них особо выделяются Милешева, Хиландарь, Беочин, Дечаны, Крушедол, Ковилье, Папорота (Папраћа), Печский монастырь, Хопово.

Типография, новшество появившееся в Европе в середине XV века, быстро проникло в сербскую среду (Медаковић 1958; Пет векова, 1994). Первая типография стала работать, под покровительством князя Георгия (Ђурђа) Црноевича, в 1494 году в Цетинском монастыpe. Тут печатник, иеромонах Макарий, напечатал Октоих (1-4 гласа), Октоих (5-8 гласа), Псалтырь (1495) и Молитвеник (1495/1496). Следующая печатня открылась в городе Горажде (в Боснии), а в ней работал Божидар Горажданин. Тут были напечатаны три книги: Служебник (1519), Псалтырь (1521), Молитвеник (1523). В монастыре Руян была напечатана всего одна книга - Евангелие тетр (1537). Под покровительством митрополита Никанора, в монастыре Грачаница напечатан Октоих (1538/9) (Грујић 1936: 81-96). В печатне которая работала в монастыре Милешева были отпечатаны три книги: Псалтырь (1544 и 1557) и Молитвеник (1546). Даже в Белграде работала типография, в которой была напечатана всего лиш одна книга - Евангелие тетр (1552).

Нам известны еще две сербские типографии приблизительно того же времени - в городе Скадре (сегодня в Албании) и при Мркшиной

${ }^{6}$ Документы опубликованы в книге Москва - Србија, Београд - Русија. Но, и до публикации этого объемистого сборника документов, отдельные документы уже привлекали внимание историков. 
церкви. Примечательно то, что почти всем перечисленым печатням покровительствовала Церковь которая очевидно попыталась таким способом возместить остро ощутимый недостаток книг. После восстановления Патриархии типографское дело в сербских землях прекратилось, возможно из-за того, что во многих монастырях снова с большим усердием стали переписвыватся книги.

Во время турецкого владычества церковь выступала не только как духовный, но и как политический вождь сербского народа. Благодаря своим мудрым и продуманым действиям, ей удалось сыграть видную роль в сохранении сербского народа и его национального самочувствия.

\section{Литература}

Богдановић Д., 1978, Каталог ћирилских рукописа манастира Хиландара, Београд.

Грујић Р., 1920, Српска православна ирква, Београд.

Грујић Р., 1936, Прва штампарија у Јужној Србији 1539. године, на Косову пољу, y манастиру Грачаници, „Гласник Скопског научног друштва” XV-XVII.

Димитријевић С., 1900, Одношаји пећких патријараха с Русијом у XVII веку, „Глас Српске Краљевске Академије” LVIII, II разред, књ. 37.

Димитријевић С., 1903, Документа која се тичу односа између српске иркве u Pусије y XVI веку, „Споменик Српске Краљевске Академије” XXXIX.

Димитријевић С., 1922, Грађа за српску историју из руских архива и библиотека, „Споменик Српске Краљевске Академије” LIII.

Драговић М., 1887, Прилози за историју Црне Горе из времена владика из разних племена, „Старине” XIX.

Ђерић В., 1909, Дванаест писама руских владалаца, „Старинар” н.с. IV.

Ђурђев Б., 1964, Улога иркве у старијој историји српског народа, Сарајево.

Ђурић В.Ј., 1985, Икона светог краља Стефана Дечанског, Београд.

Hadrovics L., 1947, Le peuple Serbe et son èglise sous la domination turque, Paris.

Ивић П., Грковић М., 1976, Дечанске хрисовуље, Нови Сад.

Јачов М., 1983, Списи Тајног ватиканског архива XVI-XVIII века, „Зборник за историју, језик и књижевност српског народа" књ. XXII, Београд.

Јачов М., 1986, Списи Конгрегачије за пропаганду вере у Риму о Србима (16221644), САНУ Зборник за историју, језик и књижевност српског народа, књ. XXVI, Београд. 
Јиречек К., 1959, Велики везир Мехмед Соколовић и српски патријарси Макарије и Антоније, Зборник Константина Јиричека I, Београд.

Јовановић Т., 1990, Пећки поменик и патријарх Пајсије, „Археографски прилози” бр. 12 , стр. $243-248$

Јовановић Т., 2001, Къижевно дело патријарха Пајсија, Београд.

Калић Ј., 1994, Срби у позном средњем веку, Београд.

Костић П., 1922, Документи о буни смедеревског епископа Павла против потчињавања Пећке патријариије Охридској архиепископији, „Споменик Српске Краљевске Академије” LVI, Други разред 48.

Медаковић Д., 1958, Графика српских штампаних књига XV-XVII века, Београд.

Милосављевић Д., 2005, Зограф Андрија Раичевић, Београд-Ужице-Прибој.

Миљковић Е., Крстић А., 2007, Браничево у XV веку, Пожаревац.

Мирковић М., 1965, Правни положај и карактер српске иркве под турском влашћу (1459-1766), Београд.

Мишић С., Суботин-Голубовић Т., 2003, Светоарханђеловска повеља, Београд.

Младеновић А., Штављанин-Ђорђевић Љ., 1982, Дијак Симон - писар српских богослужбених књига у другој половини XVI века, „Археографски прилози” бр. 4, стр. 101-146.

Момировић П., 1967, Десисалићев отачник. Стара рукописна србуља писана 1564. год. у Сарајеву, „Православна мисао” бр. 10, стр. 89-108.

Москва - Србија, Београд - Русија. Документа и материјали, 2009, т. 1, у: Друштвене и политичке везе XVI-XVIII век, прир. С. Долгова, Е. Иванова, А. Турилов, Т. Суботин-Голубовић, Београд-Москва.

Нилевић Б., 1990, Српска православна ирква у БиХ до обнове Пећке патријаршије 1557. године, Сарајево.

Новаковић С., 1923, Српска ирква у међувремену од патријарха Арсенија II до Макарија око 1459-63. до 1557, „Глас Српске Краљевске Академије” CVI.

Патријарх Пајсије, 1993, Сабрани списи, ур. Т. Јовановић, Београд.

Петковић С., 1965, Зидно сликарство на подручју Пећке патријариије (15571614), Нови Сад.

Петковић С., 1994, Пет векова српског штампарства 1494-1994, Београд.

Радоњић Ј., 1950, Римска курија и јужнословенске земље од XVI до XIX века, Београд.

Ракић 3., 1998, Радул: српски сликар ХVII века, Нови Сад.

Самарџић Р., 1993а, Туричи у српској историји, „Историја српског народа” т. III/1, Београд, стр. 7-22.

Самарџић Р., 1993б, Српска православна ирква у XVI и XVII веку, „Историја српског народа" т. III/2., Београд, стр. 7-102. 
Самарџић Р., 1993в, Обнова Пећке патријариије, „Историја српског народа” т. III/2, Београд, стр. 39-52.

Самарџић Р., 1987, Милешева и обнова српске иркве (1557), у: Милешева у историји српског народа, ур. В.Ј. Ђурић Научни скупови, књ. XXXVIII, Одељење историјских наука, књ. 6, Београд, стр. 187-194.

Самарџић Р., Веселиновић Р.Л., Поповић Т. (ур.), 1993, Историја српског народа, књ. III, т. 1, Београд.

Синдик Н., 1995, Хиландарски писар Аверкије, Проучавање средњовековних јужнословенских рукописа, Београд.

Спремић М., 1994, Деспот Бурађ Бранковић и његово доба, Београд.

Стојановић Љ., 1902, Стари српски записи и натписи, I, Београд.

Суботић Г., 1995, Иконографија св. Саве у време турске власти, књ. VII, Београд 1979.

Суботин-Голубовић Т., 1999, Српско рукописно наслеђе од 1557. године до средине XVII века, CAHУ, Посебна издања, књ. DCXL, Одељење језика и књижевности, књ. 51, Београд.

Суботин-Голубовић Т., 2004, Служба светом Ивану Рилском у српском рукописном наслеђу, „Прилози за књижевност, језик, историју и фолклор” LXVIIILXIX (за 2002-2003, обј. 2004), стр. 135-145.

Чубриловић В., 1960, Српска православна ирква под Турцима од XV до XIX века, „Зборник Филозофског факултета у Београду” бр. V-1, стр. 163-188.

Ћирковић С., 1964, Херчег Стефан Вукчић - Косача и његово доба, Београд.

Трифуновић Ђ. (ур.), 2011, Повеља краља Милутина манастиру Баљска - Светостефанска хрисовуља, т. 1-2, Београд.

Шакота М., 1956, Прилог проучавању иконописиа Лонгина, „Саопштења” бр. 1, стр. 156-166.

Шакота М., 1963, Акатист првомученику Стефану од иконописиа Лонгина, „Старине Косова и Метохије” бр. 2-3, стр. 205-213.

Шакота М., 1965, Зограф Лонгин, сликар и књижевник XVI века, Београд.

Шево Љ., 1999, Манастир Ломнииа, Београд.

Шупут М., 1984, Српска архитектура у доба турске власти 1459-1690, Београд.

Шупут М., 1991, Споменици ирквеног градитељства XVI-XVII века, Београд. 
